Çelıkkol H., \& Köse F. (2015). SWOT Analysis of Turkish Energy Market in the context of Electricity Market. Copernican Journal of Finance \& Accounting, 4(2), 27-41. http://dx.doi.org/10.12775/ CJFA.2015.014

\author{
HaKan ÇelKKol* \\ Dumlupınar University \\ FAtMA KÖSE ${ }^{* *}$ \\ Dumlupınar University
}

\title{
SWOT ANALYSIS OF TURKISH ENERGY MARKET IN THE CONTEXT OF ELECTRICITY MARKET
}

Keywords: Turkish Energy Market, Electricity Market, Liberalization, SWOT Analysis of Turkish Energy Market.

\section{J E L Classification: G18, L11, Q4.}

Abstract: Electricity energy is an indispendable part of life with continuously improving technology. Growth of the sector is unavoidable due to the increasing need of electricity. Properly functioning market structure is also important to attract investments in the sector. Therefore, plenty of steps are taken and essential changes are being done.

Even though progress has been made in regards to the process that starting with the Electricity Market Law and aims to have an electricity market that is clear, reliable, competitive, and integrated with electricity markets of other countries, it has not yet reached this desired goal. Therefore, Turkish Energy Market was decided to establish the name of more liberal and more reliable electricity market. Only electricity trading is going to be done in this market at the first step.

Date of submission: June 26, 2015; date of acceptance: October 20, 2015.

* Contact information: hakan.celikkol@dpu.edu.tr, Dumlupınar University, Faculty of Economics and Administrative Sciences, Department of Business Administration, Kütahya/Turkey, phone: +902742652031 (2058).

** Contact information: fatma.kose@dpu.edu.tr, Dumlupınar University, Faculty of Economics and Administrative Sciences, Department of Business Administration, Kütahya/ Turkey, phone: +902742652031 (2066). 
Purpose of the study is determining of potential changes in the market after Turkish Energy Market foundation. For this purpose, primarily current situation of electricity market is mentioned to understand changes that will happen in the market. Finally, weaknesses, strengths, threats and opportunities for electricity market are tried to specify by SWOT analysis.

\section{IIINTRODUCTION}

With technological advances, demand for electricity has been growing throughout the world. The increase in demand involves new investments; also it increases financial burden that required for such investments. In this context, it is observed that the adoption of liberalization in many countries, to take over the burden of high-cost electricity investment from public and in order to create more liberal market. In this context, energy stock markets have been begun to establish that electricity trade can occur at more regular structuring and in realistic prices.

In parallel to the developments in the World, it is decided to marketization of electricity market in Turkey, too and steps are being taken towards the privatization of publicly owned facilities in the structure that the public discharge the oversight and control activities effectively and observe the security of supply. Moreover, foundation of Turkish Energy Market is decided and Energy Market Management Company (EPİAŞ) was founded on 18 March 2015.

In the study, SWOT analysis of Turkish Energy Market was made in the context of electricity market.

\section{THE RESEARCH METHODOLOGY AND THE COURSE OF THE RESEARCH PROCESS}

Firstly, summary of literature was presented. Development of the electricity market in Turkey and situation of electricity market before EPİAŞ was respectively explicated. Turkish Energy Market (EPIAŞ) was clarified and then researched thoroughly by SWOT analysis. Advantages, weaknesses that the energy market has, opportunities which can be obtained and threats that might be encountered have been evaluated with a general perspective.

\section{SUMMARY OF LITERATURE}

Relevant studies about the subject could be mentioned as follows; Pagdett (1992) express single European Energy Market in the study, Christie et al. 
(1998) viewed the energy market in Norway and Sweden in the context of congestion management. Sioshansi (2005) defines electricity market reform and examine the issues despite considerable progress in understanding electricity markets. Shirmohammadi et al. (1998) define a system of advanced analytical methods and tools for secure and efficient operation of power systems in emerging energy markets in the study called "Transmission dispatch and congestion management in the emerging energy market structures". Duke and Kammen (1999) evaluate three energy-sector market transformation programs in the study that titled "The Economics Energy Market Transformation Programs". Also, Conejo et al. (2005) and Oberndorfer (2009) studied about the energy prices.

The subject of energy market is a new matter for Turkey that come to the fore. Accordingly, when making a literature review, limited availability of studies are about regulations of energy markets, operating these markets and also electricity trading.

Erten, (2012) define structure of Energy Market Management Company and its milestones. In addition to these, all the past, current and future practices of electricity trading are explained. Çiftlik, (2010) determines that energy market has a potential to be a huge market that gets attention both domestic and foreign investors. Karagöl and Mıhçıokur, (2013) focus formation of electricity market in Turkey and expectations from EPİAȘ. They also show Turkish enegy outlook and instances other energy markets in the world. Atiyas (2006), Kavak, (2009) studies liberalization of the electricity sector and new role of the state in the electricity sector in Turkey. Poyraz (2009) shows developments about the electricity competition and regulation in Turkey.

\section{DEVELOPMENT OF THE EleCtRICITY MARKET IN TURKEY}

The electrical activities are divided into three main groups including production, transmission and distribution. Up to 1990, all activities in the electricity sector in Turkey was performed Turkey Electricity Authority (TEK) that was founded by Law No. 1312 issued in 1970 as a vertical integrated public enterprise. TEK was split into two parts Turkish Electricity Generation and Transmission Company (TEAŞ) and Turkish Electricity Distribution Company (TEDAȘ), however there has not been a significant change in the basic structure of the sector (Atiyas 2006; Demirci 2010; Reel 2010). After the official announcement of candidacy for EU membership in 1999, many legal and institu- 
tional changes are made pursuant to EU harmonization, Electricity Market Law (EPK) that is compatible with union energy acquits has been published in 2001. The law has reshaped not only the relations between the attenders of public electricity sector but also the relations between other sectors of the economy, too (Başaran 2010).

TEAȘ was replaced by newly configured Electricity Generation Co. (EÜAŞ), Turkey Electricity Transmission Co. (TEIASŞ) and Turkey Electrical Contracting and Trade Inc. (TETAŞ). Electricity distribution function of TEDAŞ has been divided into 21 region within privatization (www.accenture.com, 2014; www. tedas.gov.tr, 2014). Structural changes in the Turkish electricity market are shown in Figure 1 from 1970 to present.

Figure 1. Structural Changes in Turkish Electricity Market (1970 - )

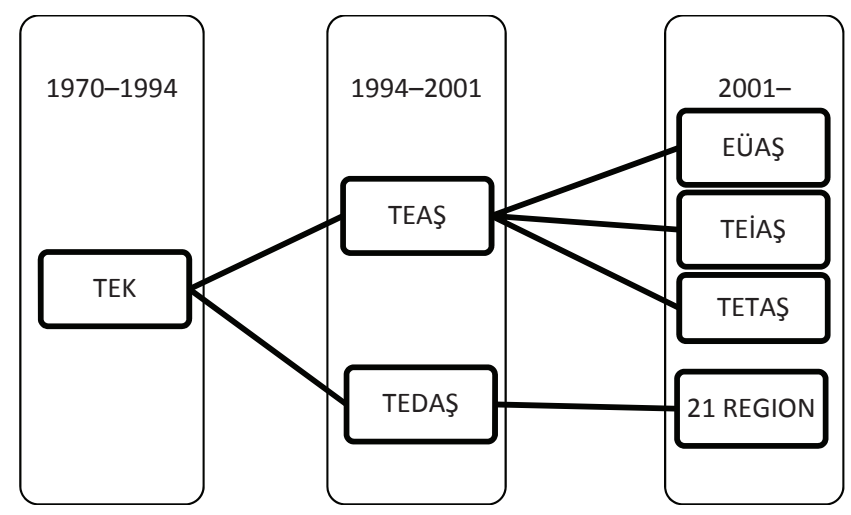

S o u r c e : www.epdk.org.tr, 2014.

The Regulatory Authority (EPDK) was founded with EPK in 2001, tender procedure was left and generation or trading possibilities are enabled to entities which can operate in the market providing that obtaining license from EPDK (Kavak 2008). In the framework the liberalization efforts, it has started the process of privatization of electricity generation and distribution, following making the required reforms in the sector (Uluatam 2011). 


\section{Situation of Electricity MARKet BEFore ENERgy MARKet (EPİAŞ)}

Electricity market is composed of spot market that consists of day ahead market and balancing market, bilateral agreements and futures market.

$80 \%-85 \%$ of the electricity spot market trading occurs at bilateral agreements, $10-15 \%$ is in the Day Ahead Market and the rest are at the real-time balancing market. Bilateral agreements are commercial treaties which are made between the natural/legal people and license holders or between legal people themselves who are license holders, subject to private law sanctions about electricity and/or capacity trading, not subject to the board approval.

Although the concept of the spot market describes instant physical trading, operations are performed before a given period of delivery in the absence of instant delivery of electricity. For this reason, the Electricity markets in many countries work as a system that is called Day Ahead Market in which the physical deliveries of transactions are performed a day earlier. Briefly, Day Ahead Market is a market that enables planning the electricity production and consumption for the next day, a day in advance. The current system is the Day Ahead Market in Turkey, too and TEIAS is responsible for the functioning of this market (Yücel 2012; Sağlam 2012). In the transition time of Day Ahead Market system, Day Ahead Planning System was implemented. Changeover was made to Day Ahead Market on 1 December 2011(TEİAŞ 2012; Faaliyet Raporu, Karagöl and Mıhçıkur 2013). Day Ahead Market expresses organized wholesale electricity market that is founded for electricity purchase and sale processes on the basis of settlement period will be delivered one day after and operated by Market Financial Settlement Center (PMUM). Participants operating in the electricity market have been able to more flexible trading environment with Day Ahead Market mechanism.

Electricity futures contracts began to be traded in Turkish Derivatives Exchange for the first time in Turkey. "VOB-Base Load Electricity Futures Contract" began to be dealt on 26 September 2011. In 2013, all stock exchanges in Turkey are gathered under a single roof at Borsa Istanbul. Since then, base load electricity futures contracts are in the scope of Main Market of Electricity Futures (www.borsaistanbul.com; Karan 2013).

A new era has begun in the electricity market with the new Electricity Market Licensing Regulation dated November 2, 2013. New Licensing Regulation that entered into force on March 30, 2013 and prepared to shape the imple- 
mentation of the new Electricity Market Law No. 6446 has made significant changes in many areas from the market structure to the obligations of the license holders and from EPDK's authorizations to the energy market. Decision on foundation of Turkish energy market (EPİAȘ) is the most important change.

\section{TURKISH ENERGY MARKET (EPIAŞ)}

As in other markets, price is formed by supply and demand equilibrium in the energy markets, too. In a free competition market, changes in demand and supply are effective on the formation of prices, also they have a determining role on the investment decisions. However, as price formation depends to free competition market, it depends on the rules that apply to these markets.

Foundation of Energy Market is planned by the new Electricity Market Law dated March 30, 2013. And after some problems encountered, EPİAŞ was officially established on March 18, 2015.

EPİAŞ conducts activities of operating organized wholesale electricity markets within market operating license except the markets which are operated by TEİAŞ and BIST. In addition, it conducts financial settlement operations of organized wholesale electricity markets that are operated by TEİAȘ within market operating license and other financial transactions. Electricity has priority at Turkish Energy Market. Besides, it is expected to include natural gas, coal and carbon in medium and long term.

Electricity market is divided into three by the new Electricity Market Law: The first is spot market operated by EPİAS, the second is balancing power market directed by TEİAS and the third one is the derivative markets operated by BİST (Karagöl and Mıhçıokur 2013). New structure of the electricity market is shown in Figure 2.

At the first step, EPİAŞ will serve as a spot market where trades only the electricity. In addition to this, derivatives on electricity trading will continue to be dealt in BİST. While intraday market specified under the control of PMUM gets involved to EPIASS, PMUM's experience, knowledge, software and information technology systems will be transferred to EPIAŞ in the new structure (Karagöl and Mıhçıokur 2013). 
Figure 2. Structure of Turkish Energy Market

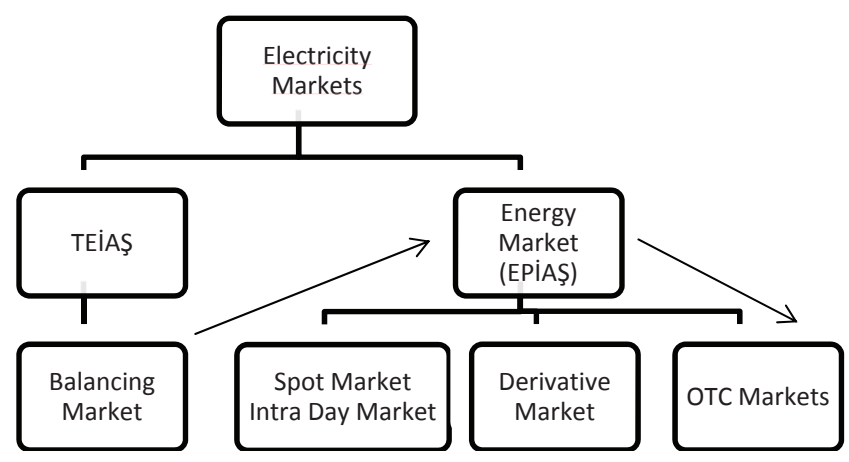

S o u r c e: Erten 2012.

Envisaged shareholder structure of EPİAŞ is aimed to be a private company not a state economic enterprise. The provision of law says "direct and indirect total share of capitals od the public institutions and state-owned companies cannot exceed fifteen percent except BIST, council of ministers have a title to increase this rate up to twice" and "The organizations that are shareholders, state-owned companies and BIST are represented at EPİAŞ management. "Capital of EPİAŞ, 61,572,770 TL, was divided to 61,572,770 shares, each of them have 1 TL nominal value and three groups were formed from these shares (Table 1). Group A shares represents $30 \%$ of the capital are reserved for TEİAŞ, Group B shares represents 30\% of the capital are reserved for BIST and Group C shares represents $40 \%$ of the capital are reserved for private sector (http://enerjienstitusu.com). BIST also got \%4,161 of Group C shares, in addition to \%30. Legal entities which have supply license or generation license in the electricity market and legal entities that are wholesale, import, export license holder or license holders performs retail legal entities in the natural gas market may have Group C shares. The minimum numbers of shares that can be owned are 50 thousand $(0.02 \%)$, the maximum number of shares are 2,462,910 (4\%). After the book building phase which lasted until 29 August 2014, total 114 companies have had a share of Group C (Dünya Gazetesi, http:// www.dunya.com). 
Table 1. Shareholding Structure of Turkish Energy Market

\begin{tabular}{|l|c|c|c|c|}
\hline \hline \multicolumn{1}{|c|}{ Shareholders } & Groups & Total share & Share Amount (TL) & Share Rate \\
\hline \hline TEIAŞ & A & 18.471 .831 & 18.471 .831 & $\% 30$ \\
\hline Borsa İstanbul & B & 18.471 .831 & 18.471 .831 & $\% 30$ \\
\hline The market participants & C & 24.629 .108 & 24.629 .108 & $\% 40$ \\
\hline \hline
\end{tabular}

Source: http://www.dunya.com.

When considering gas and oil would be included in the energy market in the future, Petroleum Pipeline Corporation (BOTAŞ) and Turkish Petroleum Corporation (TPAO) are potential partners of the energy market.

\section{SWOT ANALYSIS OF TURKISH ENERGY MARKET}

In this section of the study, SWOT analysis of Turkish Energy Market is done. Strengths, weaknesses, opportunities and threats of energy market are shown in Table 2.

Table 2. SWOT Analysis of Turkish Energy Market

\begin{tabular}{|c|c|}
\hline STRENGTHS & WEAKNESSES \\
\hline $\begin{array}{ll}\text { - } & \text { Free Market } \\
\text { - } & \text { Objectivity } \\
\text { - } & \text { Realistic Pricing } \\
\text { - } & \text { Speed } \\
\text { - } & \text { Intraday Market } \\
\text { - } & \text { Qualified Personnel }\end{array}$ & $\begin{array}{ll}\text { - } & \text { Eligible Consumer Limits } \\
\text { - } & \text { Impact of Public } \\
\text { - } & \text { Highly Cost Stamp Duty } \\
\text { - } & \text { Lack of Disclosure and Monitoring }\end{array}$ \\
\hline OPPORTUNITIES & THREATS \\
\hline $\begin{array}{l}\text { - } \text { Geographical Position } \\
\text { - Istanbul Financial Center Project } \\
\text { - } \quad \text { Derivatives Product Range } \\
\text { - Energy Thematic Funds } \\
\text { - } \quad \text { Nuclear Energy }\end{array}$ & $\begin{array}{ll}\text { - } & \text { Energy Import Dependency } \\
\text { - Impact of Public } \\
\text { - Increasing Electricity Demand and Investment } \\
\text { Financing } \\
\text { - Needs of Time and Sustainability }\end{array}$ \\
\hline
\end{tabular}

Source: The table is formed by authors.

Brief information is given about strengths, weaknesses, opportunities and threats of energy market at the next part. 


\section{STRENGTHS}

Free Market: In the current situation, spot market transactions are performed by PMUM which exist within the structure of TEİAŞ. Since TEIAŞ completely belongs to public, it prevents to operate electricity market within the framework of free market mechanism. The involvement of the private sector in the energy market enables formation of more liberal Electricity market.

Objectivity: Due to the fact that TEİAȘ belongs to public, it compromises the impartiality of the electricity markets. Therefore, market participants take a dim view of electricity trading and avoid from the market. Although its objectivity has been stated, participants can not be convinced of that, it also hinders occurring depth in the market. The presence of private sector in EPİAS management is a significant change. The market that is approved by the participants can be adopted and its objectivity could be accepted.

Realistic Pricing: This new structure that offers more reliable and more transparent environment will allows the formation of realistic prices in the spot and derivatives markets. The markets that gain functionality not only in theory but also in practice be able to reflect the actual price in cooperation with the increase in the number of investors.

Speed: State-owned projects usually progress very slowly because of bureaucracy and procedures. One of the expectations that come into existence is accelerating of the processes that occur slowly, together with that playing a part of private sector in the structure of EPİAŞ shareholder structure. Needs and the developments in the electricity market may be answered more quickly and adaptation can be achieved to competitive environment.

Intraday Market: Intraday Market is a balancing mechanism that situated between Day-Ahead Market and the Balancing Power Market and decreasing the possibility of an imbalance by creating additional buying and selling opportunities for participants. After the closing of the Day Ahead Market, the participants who place a bid can find the opportunity to reorganize the offer according to their production / consumption at Intraday Market. Intraday Market works until a few hours left for delivery, so it is important to provide the portfolio balancing opportunities in the short term. The imbalance costs can be reduced with Intraday Market that provides change to fix the forecast errors (Ay 2012).

Currently, activities are ongoing to implement this application. In this respect Intraday Market test works created by TEİAŞ began in October 2012 for 
the purpose of taking the views of market participants and gaining experience prior to application. Acceleration of the process and being implemented of Intraday Market are expected together with launching of EPİAȘ. The presence of intra-day market addition to Day Ahead Market will increase interest in the spot market (Köse 2015).

Qualified Personnel: The presence of the staff in the new structure that work in TEIAS and has experience with the system is important. However, it is observed that the large number of qualified staff transitions to the private sector. It is believed that supplying the needs of qualified personnel without causing a loss of time along with involving of the private sector in the market. Besides, the shareholder companies may contribute to the formation of more reliable market by transferring knowledge to the system (Geniş Açı 2013).

\section{WEAKNESSES}

Eligible Consumer Limits: Eligible Consumer Limits is determined by EPDK and the consumers who consume more than this limit can choose their suppliers. Eligible consumer limit is important because it is acknowledged as a free market indicator. When eligible consumer limit in Turkish electricity market was 9 million kWh in 2003, it was reduced to 4 thousand kWh in 2015 (Geniş Açı 2013, EPDK). Despite the significant decrease, eligible consumer limit could not be reset due to unhindered illegal using. This case is perceived as a weakness because it is contrary to the free market logic.

Impact of Public: Though, the electricity market has gained greatly free market qualifications with the energy market compared to the past. The presence of public shareholders at production, transmission and wholesale market is regarded as a weakness.

Highly Cost Stamp Duty: Additions of different rates of KDV or ÖTV to the products or services are common enforcements in many countries. But, stamp duty is a tax that is in Turkey and not be in other countries which prefer free market model. Trading sides are supposed to pay stamp duty in the wholesale or bilateral agreements sales and additional costs from $3 \%$ to $6 \%$ consist because of the stamp tax in the electricity and natural gas markets. The stamp duty which is paid for per contract in the bilateral agreements decelerates the growth rate of the electrical trade. In order to ensure growth and the depth in the energy market, removal of the received stamp tax from energy trading operations is required (http://www.petroturk.com). 
Lack of Disclosure and Monitoring: Electricity market in free competition can not develop sufficiently and targeted results have not been achieved. The main causes of these problems are lack of trust and uncertainty caused by lack of trust. Accordingly, deficiencies are observed related to public disclosure, monitoring and supervision. The relevant institutions must be independent, accountable and transparent in order to correct this situation with the Energy Market. Also, it should be believed its objectivity and it is under the control of experts (Çiftlik 2010).

\section{OPPORTUNITIES}

Geographical Position: Turkey's geographic position is important in terms of energy as it is in many aspects. The first step will be taken with Energy Market in order to make Turkey not only energy transit line, but also energy traded energy center. An energy market which contains especially neighboring countries can be created.

Istanbul Financial Center Project: Another important point is that the center of EPİAS will be located in Istanbul. In the circumstances, opportunities will be obtained to ensure mutual gains with Istanbul Financial Center Project which combines stock exchanges under the same roof in the same city.

Derivatives Product Range: Although the energy market includes only electrical energy derivative products initially, preparation of the futures contracts on natural gas and oil are planned in the future. Therefore, it is expected that diversity of derivative product will increase in progress of time. Moreover, the physical contracts are planned to be traded in addition to the cash contracts in the future and it is an important point that will benefit the development of the Energy Market.

Energy Thematic Funds: It is expected to increase the number of energy companies listed on the stock exchange in the future periods thanks to greater cooperation between the energy sector and the capital markets. Accordingly, energy thematic funds can be created as the examples that seen in USA, Europe and the Far East. Functioning of derivatives and spot market at the energy market by completing each other is important for the risk management of investors. After working out of energy thematic funds and different types of energy derivatives, risk management in the energy sector can be achieved in many ways. 
Nuclear Energy: The establishment of station in Turkey is important in terms of ensuring diversity resources. It is expected to lead to new opportunities with regards to territorial and regional Perspective.

\section{THREATS}

Energy Import Dependency: One of Turkey's biggest problems is the current deficit and energy import is leading factors that impact on the current deficit. As of 2014 in Turkey, the current deficit is about 45.8 billion dollars and energy import is about 54.9 billion dollars. Energy dependency poses a major threat obverse of all the developments experienced in the sector.

Impact of Public: The biggest player of natural gas market is BOTAŞ. Natural gas is used as a source for the majority of electricity generation. As seen in Figure 3, BOTAS is effective on the electricity market. As it is seen, the absence of a free natural gas market causes hesitation about totally free electricity market.

Figure 3. Electricity Production in Turkey According to Source Rate (Sep 2014)

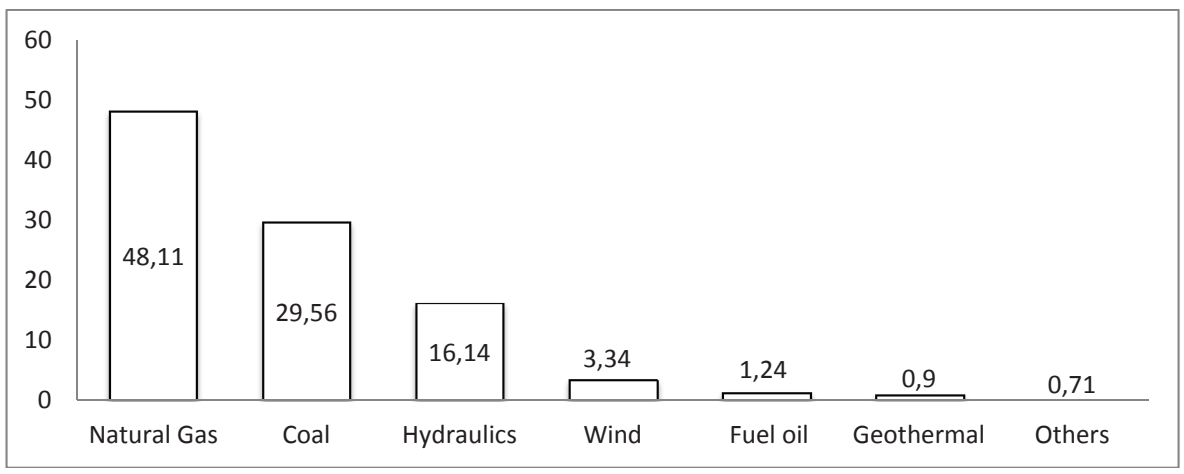

S o u r c e : http://www.enerji.gov.tr/Resources/Sites/1/Pages/Sayi_07/... (accessed: 22.07.2014).

Increasing Electricity Demand and Investment Financing: The continually increasing energy consumption is believed to be doubled in the next 10 years. It is clear that giving priority to the energy investments in order to answer the increased consumption. However, the need of resources required for such investment is a threat in point financing of investments when the lack of capital savings is considered. Another important problem related to the subject is the absence of awareness about efficient consumption. 
Needs of Time and Sustainability: Process of restructuring of Turkish Energy Market has taken longer time than planned finish date. Time will be needed again in order to coordinate the novelties which will be brought by the energy market to the sector. If the time will pass for the maturation of the market assumes to be equivalent, with the time taken to install, it would be considered a threat. Liberalization of the natural gas market as experienced in the electricity market is an important condition to mention the free energy market. When, many activities that are supposed to be done for the development and sustainability of the energy market are considered, it may be taken many years to reach the target point.

\section{ConcLusion}

Energy Market (EPİAŞ) hosts some of the weaknesses and threats together with the strengths which it have and the opportunities could be offered. It is certain that it would be a market where the price occurs more realistic and gives more confidence to investors in the electricity market according to the previous market structure. The slow functioning processes due to bureaucracy will accelerate, the number of qualified staff will increase and personnel losses can be prevented through the involvement of the private sector. Investors will be able to do their trades in the range of longer time by forming Intraday Market and so there may be an increase in the electrical trade. The advantages of Turkey's geographical position can be turned into an opportunity in the way of becoming an energy hub. Energy Market can become a regional energy exchange by including neighboring countries.

There are also some weaknesses and threats as highly cost stamp duty, eligible consumer limits, impact of public on TEİAŞ, TETAŞ and EÜAŞ, lack of disclosure and monitoring, non-free natural gas market, energy imports and increasing electricity demand and inadequate investment together with the strengths and opportunities of the energy market.

\section{REFERENCES}

Accenture, Türkiye Enerji Piyasası, Türkiye Elektrik Piyasasında Elektrik Ticareti, www.accenture.com (accessed: 10.10.2014).

Atıyas, İ. (2006). Elektrik Sektöründe Serbestleşme ve Düzenleyici Reform, Tesev Yayınları, İstanbul. 
Ay, N. (2010). Piyasa Uygulamalarında Gün Öncesi Piyasası, IV. OSB Enerji Zirvesi, 30 Ekim 2010, Van.

Ay, N. (2012). Türkiye Elektrik Piyasası, Gelişimi ve Beklentiler.

Christie, R.D., \& Wangensteen, I. (1998). The energy market in Norway and Sweden: congestion management, Power Engineering Review, IEEE, 18 (5), 61-63. http:// dx.doi.org/10.1109/39.666568.

Çıftlık, F. (2010). Elektrik Borsası, ICCI-Uluslararası Enerji ve Çevre Fuarı ve Konferansı Bildiriler Kitabı.

Conejo, A. J., Contreras, J., Espinola, R., \& Conejo, M. A. P. (2005). Forecasting electricity prices for a day-ahead pool-based electric energy market, International Journal of Forecasting, 21 (3), 435-462. http://dx.doi.org/10.1016/j.ijforecast.2004.12.005.

Demırcı, E. (2010). Enerji Vadeli İşlemleri Ve Türkiye'de Elektrik Piyasasına İlişkin Bir Uygulama, Doktora Tezi, İstanbul Üniversitesi Sosyal Bilimler Enstitüsü, İstanbul.

Duke, R., \& Kammen, D. M. (1999). The Economics Energy Market Transformation Programs, The Energy Journal, 20 (4), 15-64. http://dx.doi.org/10.5547/issn01956574-ej-vol20-no4-2.

Enerji ve Tabii Kaynaklar Bakanlığı. (2015). Dünya ve Ülkemiz Enerji ve Tabii Kaynaklar Görünümü, Ankara, http://www.enerji.gov.tr/tr-TR/Enerji-ve-Tabii-KaynaklarGorunumleri.

Erten, İ.E. (2012). EPİAŞ, Kilometre Taşları ve Fırsatlar, ICCI-Uluslararası Enerji ve Çevre Fuarı ve Konferansı Bildiriler Kitabı.

Geniş Açı Dergisi, Ekim 2013, Enerji Borsası Ne Getirecek?, http://www.isyatirim.com. tr/AssetDocs/Genis_Aci_Ekim_2013.pdf, (accessed: 16.09.2014).

http://www.borsaistanbul.com/data/egitimklavuzlari/KLVZ21VIP.PDF, (accessed: 12.08. 2014).

http://www.dunya.com/ (accessed: 12.03.2015).

http://www.enerji.gov.tr/tr-TR/Faaliyet-Raporlari/Faaliyet-Raporlari, (accessed: 22.07. 2014).

http://www.enerjienstitusu.com/2014/11/19/epias-c-grubu-pay-sahipleri-belirlendi (accessed: 10.09.2014).

http://www.epdk.org.tr/ (accessed: 07.12.2014).

http://www.petroturk.com/HaberGoster.aspx?id=11274\&haber=Damga-Vergisi (accessed: 17.02.2015).

http://www.polatenerji.com/b_enerjisektoru.php (Türkiye Enerji Sektörüne Bakış) (accessed: 12.06.2014).

http://www.tedas.gov.tr/ (accessed: 01.07.2014).

Karagöl, E. T., \& Mihçiokur, Ü. İ. (2013). Türkiye'de Enerji Borsası, Siyaset, Ekonomi ve Toplum Araştırmaları Vakfı, Seta Analiz, Sayı: 68, Ankara.

Karan, M. B. (2013). Yatırım Analizi ve Portföy Yönetimi, 4. Baskı, Gazi Kitabevi, Ankara.

Kavak, K. (2009). Elektrik Sektöründe Kamu Yönetiminin Rolü ve Önemi, Dünya Enerji Konseyi Türk Milli Komitesi, 11. Enerji Kongresi, http://www.dektmk.org.tr/ (accessed: 07.02.2015). 
Köse, F. (2015). Türkiye Elektrik Spot ve Vadeli İșlem Piyasaları Arasındaki Nedensellik İlişkisinin Analizi, Dumlupınar Üniversitesi Sosyal Bilimler Enstitüsü, Yüksek Lisans Tezi, Kütahya.

Oberndorfer, U. (2009). Energy prices, volatility, and the stock market: Evidence from the Eurozone, Energy Policy, 37 (12), 5787-5795.

Pagdett, S. (1992). The Single European Energy Market: The Politics of Realization, Journal of Common Market Studies, 30 (1), 53-76. http://dx.doi.org/10.1111/ j.1468-5965.1992.tb00418.x.

Poyraz, M. (2009). Elektrik Endüstrisinde Rekabet Ve Regülasyonun Türkiye'de İzlediği Seyir, 11. Enerji Kongresi, http://www.dektmk.org.tr/pdf/enerji_kongresi_11/10. pdf (accessed: 07.02.2015).

Reel, Y. (2010). Elektrik Sektörünün Regülasyonu, Enerji, Piyasa ve Düzenleme, Cilt:1, Sayı:2, 194-218.

Sağlam, B. (2012). Monopolden Emtia Piyasasına: Emtia Piyasası Yaklaşımıyla Elektrik Piyasalarındaki Dönüşüm Sürecinin Rekabetçi Analizi, Uzmanlık Tezi, Rekabet Kurumu, Ankara.

Shormohammadi, D., Wollenberg, B., Vojdani, A., Sandrin, P., Perreira, M., Rahim, F., Schneider, T. \& Stott, B. (1998). Transmission dispatch and congestion management in the emerging energy market structures, IEEE Transactions on Power Systems, 13 (4), 1466-1474. http://dx.doi.org/10.1109/59.736292.

Sioshansi, F.P. (2006). Electricity market reform: What has the experience taught us thus far?, Utilities Policy, 14 (2), 63-75. http://dx.doi.org/10.1016/j.jup.2005.12.002.

Uluatam, E. (2011). Türkiye Elektrik Piyasasında Özelleştirme Süreci, Ekonomik Forum Dergisi.

Yücel, C. Ö. (2012). Elektrik Üretiminde Hakim Durumun Tespiti, Uzmanlık Tezi, Rekabet Kurumu, Ankara. 
